\title{
Towards Industrial Energy Efficiency Index
}

\author{
Kristiāna DOLGE ${ }^{*}$, Anna KUBULE ${ }^{2}$, Stelios ROZAKIS ${ }^{3}$, Inga GULBE ${ }^{4}$, \\ Dagnija BLUMBERGA ${ }^{5}$, Oskars KRIEVS ${ }^{6}$ \\ 1,2,4-6Institute of Energy Systems and Environment, Riga Technical University, Azenes iela 12/1, \\ Riga, LV-1048, Latvia \\ ${ }^{3}$ School of Environmental Engineering, Technical University of Crete, 73100 Chania, Greece
}

\begin{abstract}
The study analyses factors that determine industrial energy efficiency. Composite index methodology was applied to evaluate energy utilization efficiency levels across different industrial sub-sectors. In total 12 indicators were incorporated in 3 main dimensions economic, technical, and environmental. The first results for dimension sub-indices of the 18 main manufacturing sub-sectors in Latvia were presented and discussed. The findings of the study indicated that sector-specific disparities exist that significantly impact the energy efficiency performance of each industrial sub-sector.
\end{abstract}

Keywords - Composite index; dimensions; energy efficiency; performance indicators; sub-sectoral comparison.

\begin{tabular}{|ll}
\hline Nomenclature & \\
$E E I$ & Energy efficiency index \\
$I_{\mathrm{N}^{+}}$ & Normalized indicator of a positive influence on energy efficiency \\
$I_{\mathrm{N}^{-}}$ & Normalized indicator of a negative influence on energy efficiency \\
$I_{\mathrm{act}}$ & Actual value of an indicator \\
$I_{\max }$ & Maximum value of an indicator \\
$I_{\min }$ & Minimum value of an indicator \\
$I_{\mathrm{D}}$ & Dimension sub-index \\
$w_{\mathrm{I}}$ & Determined weight of an indicator \\
$w_{\mathrm{D}}$ & Determined weight of a dimension \\
$n_{\mathrm{I}}$ & Number of indicators in a dimension \\
$n_{\mathrm{D}}$ & Number of dimensions \\
\hline
\end{tabular}

\section{INTRODUCTION}

Nowadays all companies in the industrial sector are confronted with the energy efficiency issue since manufacturing processes are highly reliable in terms of amount of energy consumed. The total energy efficiency of industry is highly dependent on the sectoral heterogeneity [1] since the technological processes and generated economic output of the produced items of sub-sectors

\footnotetext{
* Corresponding author.

E-mail address: kristiana.dolge@rtu.lv

(C)2020. Kristiāna Dolge, Anna Kubule, Stelios Rozakis, Inga Gulbe, Dagnija Blumberga, Oskars Krievs. 
differ. Therefore, in respect to industrial energy efficiency assessment it is crucial to develop a model that measures sectors separately and investigates sectoral differences [2].

When it comes to macroeconomic evaluation of energy efficiency among different sectors in the industry, the question about the choice of the most appropriate and comprehensive evaluation method arises. Numerous studies investigate energy efficiency performance levels across different sectors that include in-depth analysis of several factors of energy efficiency separately. However, when there exist many different performance indicators it might be difficult to make sub-sectoral comparisons based on different units of measurement of each indicator [3].

The goal of this study is to demonstrate the application of an innovative model for industrial energy efficiency evaluation. The composite index methodology is used to construct 3 sub-indices for each dimension of energy efficiency - economic, technical, and environmental, for 18 different manufacturing sub-sectors in Latvia. Composite indices are a common practice in the sustainability evaluation studies [3]-[5], therefore, this study aims to demonstrate that a similar approach could be used in energy efficiency research to obtain valuable findings for policymakers. This study focuses on the analysis on 12 different indicators that were incorporated in the selected dimensions of energy efficiency. Preliminary results on each dimension's sub-indices are presented and discussed

\section{Methodology}

Energy efficiency index (EEI) in this study is a composite measure that compares energy utilization efficiency levels among various industrial sub-sectors. The index is composed of three main energy efficiency dimensions that each consists of four explanatory indicators. The model for the composition of the EEI proceeds in several chronological stages that are illustrated in Fig. 1. The proposed model in the study is developed by using the methodological approach applied in the academic studies on sustainability evaluation [3], [4], [6], [7], as well as taking into consideration the composite index calculation practices applied in the internationally recognized reports published by the European Commission (for eco-innovation index), the United Nations (for human development index), and in relevant scientific peer-reviewed papers [5], [8].

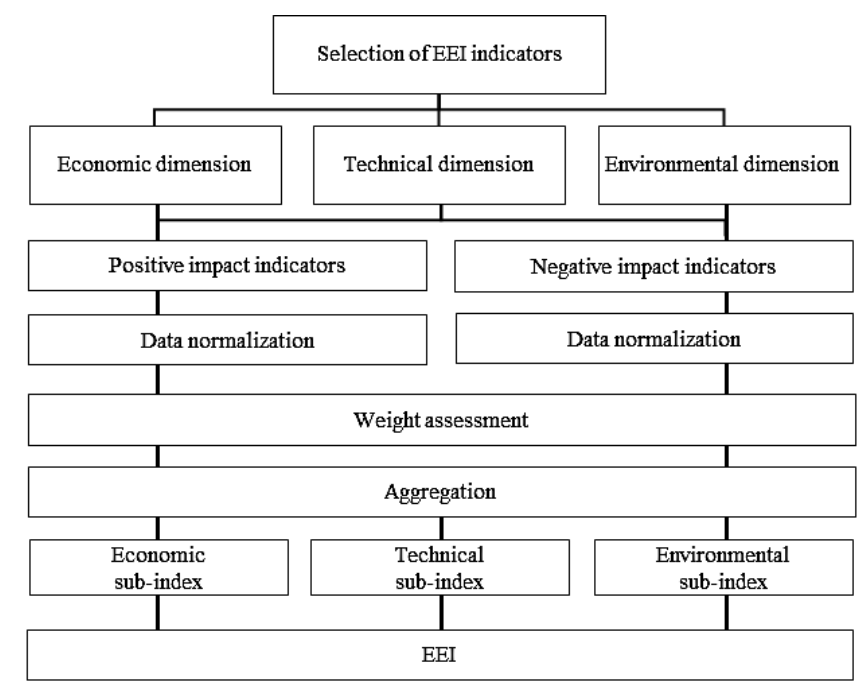

Fig. 1. Hierarchical procedure of the EEI calculation. Developed by the authors inspired by [3], [4], [6], [7]. 


\subsection{Data Collection on Selected Indicators}

Based on data availability in total 12 relevant indicators on 18 main industrial sub-sectors in Latvia were selected. Data on sub-sectors were collected and grouped according to NACE Rev. 2 classification [9]. Data were collected from Eurostat, Central Statistical Bureau of Latvia (CSB) and International Organization for Standardization (ISO) databases. All sources of the data used in the study are listed in Table 1. All the data reported in the study are for the year 2017, with an exception of data for environment protection activity from Eurostat's Community Innovation Survey (CIS) questionnaire that was collected for the latest available year. In addition, in data processing there were detected missing data on the year 2017 for the manufacture sector of computer, electronic and optical products. As a result, the values were taken for the year 2015 for the sectors. According to the performed sensitivity analysis, it did not impact the results.

\subsection{Classification of the Indicators}

Classification of the indicators into dimensions is commonly used in composite sustainability indices studies ([4], [10], [11]), therefore, selected indicators were grouped in three dimensions of energy efficiency - economic, technical and environmental, as presented in Table 1.

Indicators of the economic dimension reflect a sector's ability to generate sufficient economic contribution relative to the amount of energy consumed in the production process. Strong economic performance is a significant determinant for achieving higher energy efficiency [12] since the economic growth stimulate companies to invest in renewable energy technologies in order to replace the utilization of the fossil fuels [13]. Indicators identifying to the economic dimension consist of the following independent variables - value added per energy use, generated turnover per energy use, energy costs, and energy taxes per generated turnover.

Technical dimension's indicators cover both technical and structural aspects of manufacturing companies in the sectors. Access to capital, technical support, labour intensity, and sector size are some of the factors that should be considered in the concept of industrial sustainability and energy efficiency [14]. These aspects are incorporated in the technical dimension by the following variables - investment per energy use, share of ISO 50001 registered companies, share of largesized companies, and energy use per employee.

The group of environmental indicators concern the environmental impact the sectors create as a result of their economic activity. The amount of produced greenhouse gases, including $\mathrm{CO}_{2}$ emissions, are strongly linked with energy efficiency in the manufacturing industry [15], [16]. To measure the performance of the environmental dimension, the following independent variables were incorporated - greenhouse gas intensity, use of fossil energy resources, environment protection activity, and $\mathrm{CO}_{2}$ productivity.

All the factors incorporated in each dimension and within the framework of the index methodology are believed to be interconnected and jointly create synergies towards the determination of the index [17].

\subsection{Impact Evaluation}

Each indicator is evaluated with respect to its impact on energy efficiency. Indicators are grouped in two categories depending on their positive or negative influence on energy efficiency. An indicator has a positive impact if its increasing value contributes to the improvement of energy efficiency (e.g. generated value added per unit of consumed energy). In turn, an indicator has a negative impact if its increasing value negatively deteriorates sustainable energy efficiency goals (e.g. produced greenhouse gases per generated value added) [10]. Table 1 incorporates the results from the impact evaluation. 
TABLE 1. DATA SOURCES, INDICATOR CLASSIFICATION AND IMPACT EVALUATION

\begin{tabular}{|c|c|c|c|c|}
\hline Dimension & Indicator & Variable & Impact & Data source \\
\hline \multirow[t]{4}{*}{ Economic } & $\begin{array}{l}\text { Value added per } \\
\text { energy use }\end{array}$ & Value added/Net domestic energy use & + & [18], [19] \\
\hline & $\begin{array}{l}\text { Generated turnover } \\
\text { per energy use }\end{array}$ & Turnover/Net domestic energy use & + & {$[18],[19]$} \\
\hline & Energy costs & Purchases of energy products/Turnover & - & {$[20],[18]$} \\
\hline & $\begin{array}{l}\text { Energy taxes per } \\
\text { generated turnover }\end{array}$ & Energy taxes/Turnover & - & [21], [18] \\
\hline \multirow[t]{4}{*}{ Technical } & $\begin{array}{l}\text { Investment per } \\
\text { energy use }\end{array}$ & $\begin{array}{l}\text { Gross investment in existing buildings, } \\
\text { structures, machinery and equipment, } \\
\text { construction and alteration of } \\
\text { buildings/Net domestic energy use }\end{array}$ & + & [18], [19] \\
\hline & $\begin{array}{l}\text { Share of ISO } 50001 \\
\text { registered companies }\end{array}$ & $\begin{array}{l}\text { Number of ISO } 50001 \text { registered } \\
\text { companies/Total number of companies }\end{array}$ & + & [22], [18] \\
\hline & $\begin{array}{l}\text { Share of large size } \\
\text { companies }\end{array}$ & $\begin{array}{l}\text { Number of enterprises with } 250 \text { persons } \\
\text { or more employed /Total number of } \\
\text { enterprises }\end{array}$ & + & {$[23]$} \\
\hline & $\begin{array}{l}\text { Energy use per } \\
\text { employee }\end{array}$ & $\begin{array}{l}\text { Net domestic energy use/Number of } \\
\text { employees }\end{array}$ & - & [19], [18] \\
\hline \multirow[t]{4}{*}{ Environmental } & $\begin{array}{l}\text { Greenhouse gas } \\
\text { intensity }\end{array}$ & Tons of greenhouse gases/Value added & - & {$[24],[18]$} \\
\hline & $\begin{array}{l}\text { Use of fossil energy } \\
\text { resources }\end{array}$ & $\begin{array}{l}\text { Fossil energy products/Total energy } \\
\text { products }\end{array}$ & - & {$[25]$} \\
\hline & $\begin{array}{l}\text { Environment } \\
\text { protection activity }\end{array}$ & $\begin{array}{l}\text { Percentage of companies that reduced } \\
\text { energy consumption or } \mathrm{CO}_{2} \text { emissions }\end{array}$ & + & [26] \\
\hline & $\mathrm{CO}_{2}$ productivity & $\begin{array}{l}\text { Generated turnover/Tons of } \mathrm{CO}_{2} \\
\text { emissions }\end{array}$ & + & {$[18],[24]$} \\
\hline
\end{tabular}

\subsection{Data Normalization}

In order to transform all the indicators into a common scale, min-max data normalization is applied. Normalization stage expresses all the different units of measurement of the indicators into a common ranking unit. The values are ranked in a range from 0 to 1 , where 0 being the lowest and 1 the highest grade. Indicators are normalized taking into account the results from the indicator impact evaluation. Normalization for positive impact indicators is performed using Eq. (1) and for negative impact indicators using Eq. (2).

$$
\begin{gathered}
I_{\mathrm{N}}^{+}=\frac{I_{\mathrm{act}}-I_{\min }}{I_{\mathrm{max}}-I_{\min }} ; \\
I_{\mathrm{N}}^{-}=1-\frac{I_{\mathrm{act}}-I_{\text {min }}}{I_{\text {max }}-I_{\text {min }}},
\end{gathered}
$$

where

$\mathrm{I}_{\mathrm{N}}{ }^{+} \quad$ Normalized indicator of a positive impact; 
$I_{\mathrm{N}}^{-} \quad$ Normalized indicator of a negative impact;

$I_{\text {act }} \quad$ Actual value of an indicator;

$I_{\max } \quad$ Maximum value of an indicator among the values in the sector;

$I_{\min } \quad$ Minimum value of an indicator among the values in the sector.

\subsection{Weight Assessment}

After data normalization, weights are determined for each indicator and their respective dimensions. Several weighting techniques are available such as equal weighting, expert weighting, pair-wise comparison, analytic hierarchy process (AHP), and others [6]. In this study equal weighting is applied in order to maximize the objectivity of the obtained results and emphasize the equal importance of all factors considered as stressed in various sustainability studies [4]. Equal weights are assigned to all indicators.

\subsection{Aggregation}

The final composition of the EEI consists of two main stages. At first, all the sub-indices of each dimension are calculated by aggregating normalized and weighted indicators according to Eq. (3). Then EEI is calculated by combining the values of each sub-index with its corresponding weight as shown in Eq. (4).

$$
\begin{gathered}
I_{\mathrm{D}}=\sum w_{\mathrm{I}} \cdot I_{\mathrm{N}}^{+}+\sum w \cdot I_{\mathrm{N}}^{-}, w_{\mathrm{I}}=\frac{1}{n_{\mathrm{I}}} \\
E E I=\sum w_{\mathrm{D}} \cdot I_{\mathrm{D}}, w_{\mathrm{D}}=\frac{1}{n_{\mathrm{D}}},
\end{gathered}
$$

where

$I_{\mathrm{D}} \quad$ Sub-index of a particular dimension;

$w_{\mathrm{I}} \quad$ Weight of an indicator;

$w_{\mathrm{D}} \quad$ Weight of a dimension;

$n_{\mathrm{I}} \quad$ Number of indicators in a dimension;

$n_{\mathrm{D}} \quad$ Number of dimensions.

\section{RESUlts}

Energy efficiency dimension sub-indices for 18 main industrial sub-sectors in Latvia have been constructed for the year 2017. Based on the most recent, publicly available data a total 12 indicators were incorporated in 3 dimensions of energy efficiency - economic, technical, and environmental. Each dimension consisted of 4 partial explanatory indicators. Table 2 summarizes the results from 3 sub-indices. It is evident that the values of dimension sub-indices differ considerably among all the sectors.

The highest average value of 0.48 was achieved in the environmental dimension sub-index, following by the technical dimension sub-index with 0.35 and the economic dimension sub-index with 0.34 . The economic dimension values range from 0.03 to 1 , technical dimension values range from 0.03 to 0.75 , and environmental dimension values range from 0.06 to 0.72 . 
TABLE 2. RESUltS FOR ECONOMIC, TECHNICAL AND ENVIRONMENTAL DIMENSION SUB-INDICES

\begin{tabular}{|c|c|c|c|}
\hline Sector & $\begin{array}{l}\text { Economic dimension } \\
\text { sub-index }\end{array}$ & $\begin{array}{l}\text { Technical dimension } \\
\text { sub-index }\end{array}$ & $\begin{array}{l}\text { Environmental dimension } \\
\text { sub-index }\end{array}$ \\
\hline $\begin{array}{l}\text { Computers, electronics, } \\
\text { optics }\end{array}$ & 1.00 & 0.38 & 0.72 \\
\hline Electrical equipment & 0.49 & 0.50 & 0.58 \\
\hline Pharmaceuticals & 0.44 & 0.75 & 0.37 \\
\hline Printing and media & 0.41 & 0.54 & 0.56 \\
\hline Machinery and equipment & 0.39 & 0.42 & 0.64 \\
\hline $\begin{array}{l}\text { Motor vehicles and } \\
\text { trailers }\end{array}$ & 0.46 & 0.44 & 0.53 \\
\hline Fabricated metals & 0.40 & 0.39 & 0.51 \\
\hline Rubber and plastics & 0.34 & 0.40 & 0.53 \\
\hline Other transport equipment & 0.18 & 0.37 & 0.58 \\
\hline Textiles, clothing, leather & 0.38 & 0.30 & 0.40 \\
\hline $\begin{array}{l}\text { Food, beverages and } \\
\text { tobacco }\end{array}$ & 0.32 & 0.31 & 0.44 \\
\hline Paper & 0.36 & 0.30 & 0.39 \\
\hline $\begin{array}{l}\text { Furniture and other } \\
\text { manufacturing }\end{array}$ & 0.28 & 0.32 & 0.42 \\
\hline Chemicals & 0.27 & 0.19 & 0.54 \\
\hline Basic metals & 0.25 & 0.21 & 0.48 \\
\hline Mining and quarrying & 0.13 & 0.30 & 0.28 \\
\hline Wood and cork & 0.03 & 0.08 & 0.56 \\
\hline Non-metallic minerals & 0.03 & 0.03 & 0.06 \\
\hline Average & 0.34 & 0.35 & 0.48 \\
\hline
\end{tabular}

The economic dimension was the only one that reported the highest possible grade of 1 that was reached by the manufacturing sector of computer, electronic and optical products. The highest grade of 0.75 in the technical dimension sub-index was achieved by the pharmaceuticals manufacturing sector. Moreover, in the environmental dimension the computer, electronic and optical product manufacturing sector again scored highest with a value of 0.72. Fig. 2 illustrates the indicator values achieved in each dimension sub-index.

The other outstanding sectors of the economic dimension sub-index were electrical equipment manufacturing with a value of 0.49 , motor vehicles manufacturing with a grade of 0.46 , and the pharmaceutical product manufacturing sector with a value of 0.51

In contrast, the non-metallic minerals manufacturing sector indicated the lowest values in all the dimension sub-indices. Moreover, other underperforming sectors of the economic dimension subindex were wood and cork manufacturing with a score of 0.03 and mining and quarrying with a score of 0.13 . 


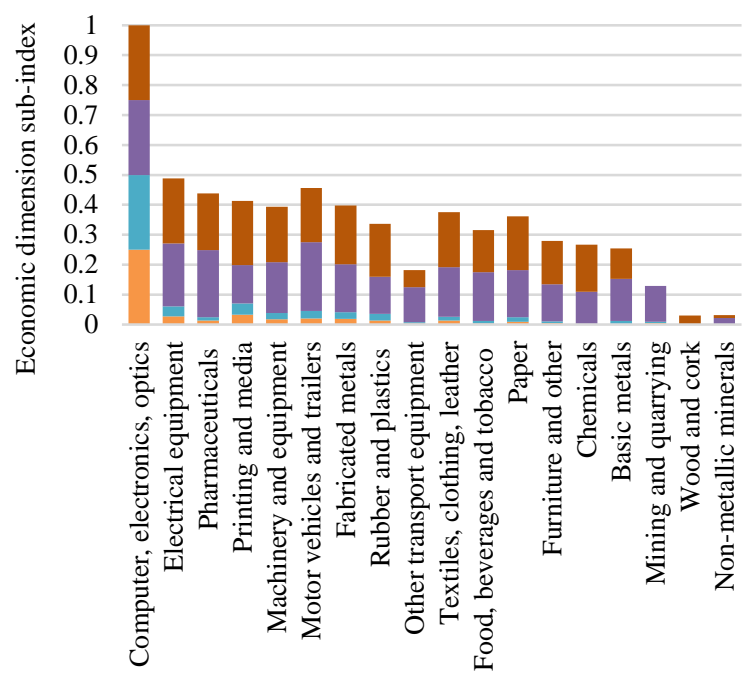

- Energy taxes per generated turnover

- Energy costs

- Generated turnover per energy use

$\square$ Value added per energy use

(a)
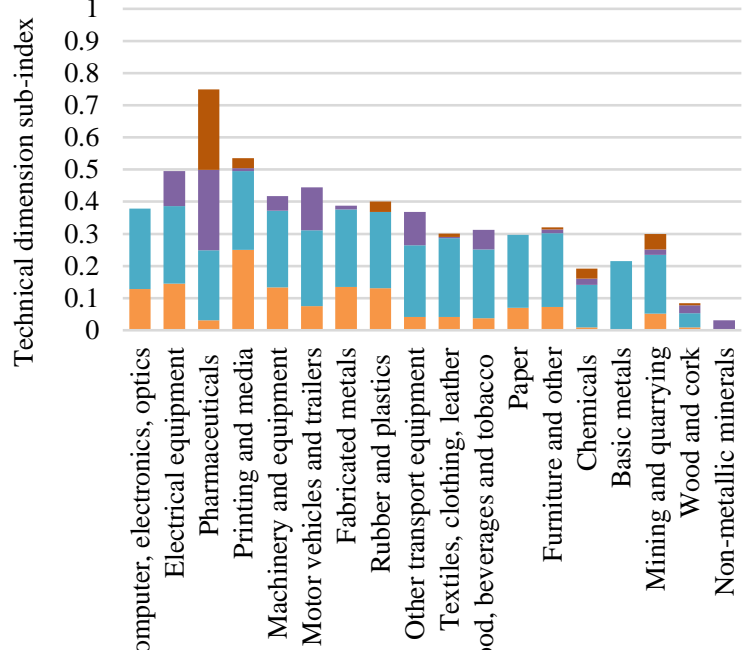

- Share of ISO 50001 registered companies

- Share of large size companies

- Energy use per employee

- Investment per energy use

(b) 


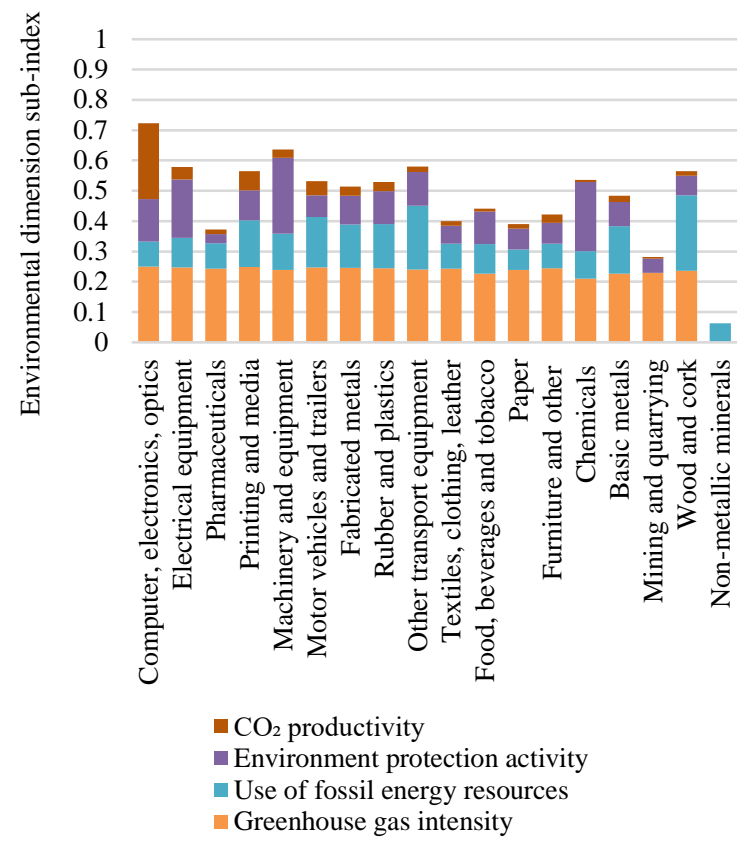

(c)

Fig. 2. Results for the a) economic, b) technical, c) environmental dimension sub-indices of EEI.

The results of the economic dimension sub-index suggest that producing more sophisticated or lightweight end products constitutes to higher energy utilization efficiency levels. However, manufacture of primary products and raw materials are associated with lower energy efficiency. This result is explained by the sectors' ability to generate sufficient economic value relative to the amount of energy consumed. The more a sector's economic activity contributes to the industry's gross domestic product and generated value added, the more justified are the amounts of energy consumed.

When analysing indicator values of the economic dimension in more detail, it can be observed that for the economic dimension a crucial role is for the indicators of energy expenses that is measured by the purchases of energy products and energy taxes per turnover. For most of the sectors, these indicator values contributed the most to the economic dimension sub-index. The competitive advantage of computer, electronic and optical products manufacturing sector is that in addition to high values in these indicators, it also reported equally high values for generated turnover and value added per energy use indicators. As a result, ranking the sector ranks substantially higher compared to other sectors.

For the technical dimension, energy use per employee and investment made per energy use played a significant role in contributing to the overall value of the sub-index. The pharmaceuticals manufacturing sector stood out with the highest sub-index value that was achieved thanks to a higher share of large-sized companies and ISO 50001 registered companies in a sector compared to the others.

In the environment dimension, the use of fossil energy resources and greenhouse gas intensity indicator values were the most significant determinants of the overall value of the sub-index. The manufacturing sector of computer, electronic and optical products proved to be an absolute 
leader in the environment dimension due to higher $\mathrm{CO}_{2}$ productivity compared to other sectors. Wood and cork manufacturing sector achieved high overall environment dimension sub-index value, however, it indicated underperforming results of the economic and technical dimension sub-indices.

At the current stage of the study, descriptive analysis of the obtained dimension sub-indices in each sector was executed and dominant relationships among the sectors was examined. Based on the normalized sum of partial indices, the sector naïve ranking appears in Table 2. Based on Pareto efficiency it is possible to distinguish between two groups, namely the 5 first sectors that are nondominated and the rest 13 sectors that are dominated by the leading sectors such as computer, electronics, optics manufacturing or the electrical equipment manufacturing. In other words, if the weights are assigned to economic, technical and environmental dimensions, none of the sectors belonging to the second group would outrank any one of the first group sectors. On the other hand, among the first five, we are not able to rank unless we assign weights. Further analysis is required to come up with a factor that could adequately rank the sectors on their overall energy efficiency. Thus, the final Energy Efficiency Index (EEI) has not yet been obtained and the next methodological step that consist of the aggregation of each dimension's sub-index will be performed in further research.

\section{Conclusions}

The findings of the study reported that energy efficiency levels of each dimension appear to be different among the 18 sub-sectors of the manufacturing industry. The differences are observed in all three dimensions of energy efficiency - economic, technical, and environmental. The results revealed that knowledge-intensive sectors that produce more complex and sophisticated products such as computer, electronics, optics manufacturing, electrical equipment manufacturing, and pharmaceuticals manufacturing are associated with higher economic dimension sub-index values of energy efficiency. However, primary manufacturing sectors that produce industrial raw materials such as non-metallic minerals manufacturing, wood and cork manufacturing, mining and quarrying are associated with lower energy efficiency levels in most of the representative dimensions.

The proposed model combines various indicators of industrial energy efficiency into a common scale, therefore allowing to easily identify sub-sectoral differences in each dimension of energy efficiency. The model could be calibrated and used as a tool for policymakers to develop sector specific legislation and requirements related to energy management practices. As a result, more efficient policy instruments could be developed in order to increase the industry engagement towards the implementation of the energy efficiency activities [27].

Further research will focus on incorporating all the dimensions in one final Energy Efficiency Index (EEI) to obtain final numbers of energy efficiency levels for all sectors reviewed in this study. To investigate dynamics and evolution of EEI and its dimension sub-indices over time, the index could be constructed for different time periods. It would allow to identify those sub-sectors that showed improvements towards energy efficiency goals [28]. Moreover, in further research additional indicators could be added for each dimension to increase the explanatory power of each dimension's sub-index. In addition, further research could experiment with the application of different weighting techniques and included indicators in order to validate the overall model. 


\section{ACKNOWLEDGEMENT}

This research is funded by the Ministry of Economics of the Republic of Latvia, project "The pathway to energy efficient future for Latvia (EnergyPath)", project No. VPP-EM-EE-2018/1-0006.

\section{REFERENCES}

[1] Liao N., He Y. Exploring the effects of influencing factors on energy efficiency in industrial sector using cluster analysis and panel regression model. Energy 2018:158:782-795. https://doi.org/10.1016/j.energy.2018.06.049

[2] Trotta G. Assessing energy efficiency improvements and related energy security and climate benefits in Finland: An ex post multi-sectoral decomposition analysis. Energy Economics 2020:86:104640. https://doi.org/10.1016/j.eneco.2019.104640

[3] Krajnc D., Glavič P. How to compare companies on relevant dimensions of sustainability. Ecological Economics 2005:55(4):551-563. https://doi.org/10.1016/j.ecolecon.2004.12.011

[4] Barrera-Roldán A., Saldívar-Valdés A. Proposal and application of a Sustainable Development Index. Ecological Indicators 2002:2(3):251-256. https://doi.org/10.1016/S1470-160X(02)00058-4

[5] Lemke C., Bastini K. Embracing multiple perspectives of sustainable development in a composite measure: The Multilevel Sustainable Development Index. Journal of Cleaner Production 2020:246:118884. https://doi.org/10.1016/j.jclepro.2019.118884

[6] Mazziotta M., Pareto A. Methods for Constructing Composite Indices: One for All or All for One? RIEDS - Rivista Italiana di Economia Demografia e Statistica 2013:67(2):67-80.

[7] Razmjoo A. A., Sumper A., Davarpanah A. Development of sustainable energy indexes by the utilization of new indicators: A comparative study. Energy Reports 2019:5:375-383. https://doi.org/10.1016/j.egyr.2019.03.006

[8] Park M. S., et al. Eco-innovation indices as tools for measuring eco-innovation. Sustainability 2017:9(12):2206. https://doi.org/10.3390/su9122206

[9] European Commission. NACE Rev. 2 - Statistical classification of economic activites in the European Community. Luxembourg: Office for Official Publications of the European Communities, 2008.

[10] Krajnc D., Glavič P. A model for integrated assessment of sustainable development. Resource Conservation and Recyclyng 2005:43(2):189-208. https://doi.org/10.1016/j.resconrec.2004.06.002

[11] Cîrstea S. D., et al. Evaluating renewable energy sustainability by composite index. Sustainability 2018:10(3):811. https://doi.org/10.3390/su10030811

[12] Marques, A. C., Fuinhas, J. A., and Tomás, C. Energy efficiency and sustainable growth in industrial sectors in European Union countries: A nonlinear ARDL approach. Journal of Cleaner Production 2019:239:118045. https://doi.org/10.1016/j.jclepro.2019.118045

[13] Abdollahi, H. Investigating Energy Use, Environment Pollution, and Economic Growth in Developing Countries. Environ. Clim. Technol. 2020:24(1):275-293. https://doi.org/10.2478/rtuect-2020-0016

[14] Trianni, A., Cagno, E., \& Neri, A. Modelling barriers to the adoption of industrial sustainability measures. J. Clean. Prod. 2017:168:1482-1504. https://doi.org/10.1016/j.jclepro.2017.07.244

[15] Pérez K., González-Araya M. C., Iriarte A. Energy and GHG emission efficiency in the Chilean manufacturing industry: Sectoral and regional analysis by DEA and Malmquist indexes. Energy Economics 2017:66:290-302 https://doi.org/10.1016/j.eneco.2017.05.022

[16] Sutthichaimethee P., Ariyasajjakorn D. Forecast of Carbon Dioxide Emissions from Energy Consumption in Industry Sectors in Thailand. Environmental and Climate Technologies 2018:22(1):107-117. https://doi.org/10.2478/rtuect2018-0007

[17] Harik R., et al. Towards a holistic sustainability index for measuring sustainability of manufacturing companies. International Journal of Production Research 2015:53(13):4117-4139. https://doi.org/10.1080/00207543.2014.993773

[18] Eurostat. Annual detailed enterprise statistics for industry (NACE Rev. 2, B-E) [Online]. [Accessed: 10.02.2020]. Available: https://appsso.eurostat.ec.europa.eu/nui/show.do?dataset=sbs_na_ind_r2\&lang=en

[19] Eurostat. Key indicators of physical energy flow accounts by NACE Rev. 2 activity [Online]. [Accessed: 10.02.2020]. Available: https://appsso.eurostat.ec.europa.eu/nui/show.do?dataset=env_ac_pefa04\&lang=en

[20] Central Statistics Bureau of Latvia. Entrepreneurship indicators of enterprises (SBG010) [Online]. [Accessed: 10.02.2020]. Availeble: http://data1.csb.gov.lv/pxweb/en/uzn/uzn_uzndarb/SBG010.px

[21] Eurostat. Environmental taxes by economic activity (NACE Rev. 2) [Online]. [Accessed: 02.10.2020]. Available: https://appsso.eurostat.ec.europa.eu/nui/show.do?dataset=env_ac_taxind2\&lang=en

[22] International Organization for Standardization. The ISO Survey of certifications to management system standards Full results. Geneva: ISO, 2018. 
[23] Eurostat. Industry by employment size class (NACE Rev. 2, B-E) [Online]. [Accessed: 17.02.2020]. Available: https://appsso.eurostat.ec.europa.eu/nui/show.do?dataset=sbs_sc_ind_r2\&lang=en

[24] Eurostat. Air emissions accounts by NACE Rev. 2 activity [Online]. [Accesed 02.04.2020]. Available: https://appsso.eurostat.ec.europa.eu/nui/show.do?dataset=env_ac_ainah_r2\&lang=en

[25] Eurostat. Energy supply and use by NACE Rev. 2 activity [Önline]. [Accessed 02.03.2020]. Available: https://appsso.eurostat.ec.europa.eu/nui/show.do?dataset=env_ac_pefasu\&lang=en

[26] Eurostat. Environmental benefits due to innovation in the enterprises by NACE Rev. 2 activity and size class [Online]. [Accessed 02.03.2020]. Available: https://appsso.eurostat.ec.europa.eu/nui/show.do?dataset=inn_cis9_env\&lang=en

[27] Locmelis K., Bariss U., Blumberga D. Energy Efficiency Obligations and Subsidies to Energy Intensive Industries in Latvia. Environmental and Climate Technologies 2019:23(2):90-101. https://doi.org/10.2478/rtuect-2019-0057

[28] Zuberi M. J. S., et al. A detailed review on current status of energy efficiency improvement in the Swiss industry sector. Energy Policy 2019:137:111162. https://doi.org/10.1016/j.enpol.2019.111162

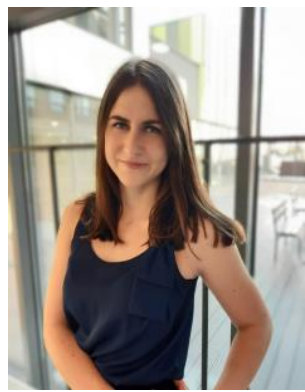

Kristiāna Dolge, M. sc. ing. student, research assistant. Main research areas are evaluation of energy efficiency potential, sectorial comparisons, industrial energy efficiency, development of composite indices, index methodology application for bioeconomy and RES sustainability assessment.

E-mail: Kristiana.Dolge@rtu.lv
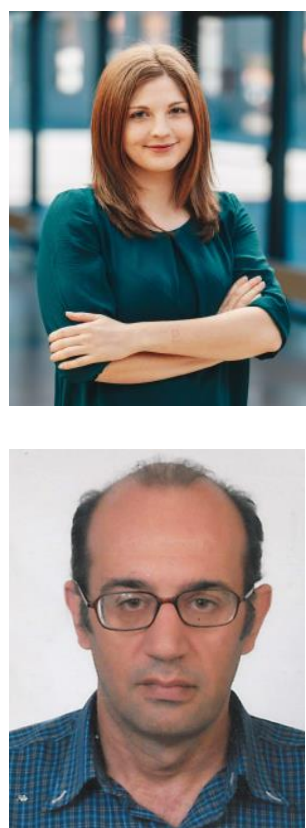

Anna Kubule, Dr. sc. ing. earned the degree in environmental engineering from Riga Technical University in 2016.

She has been working in environmental engineering field since 2010 and is currently the Leading researcher at the Institute of Energy Systems and Environment at Riga Technical University. Here expertise includes research on resource and energy efficiency, industrial symbiosis and bioeconomy.

E-mail: anna.kubule@rtu.lv

ORCID: http://orcid.org/0000-0002-0518-3163

Stelios Rozakis is an Associate Professor and director of the Bioeconomy and Biosystem Economics Lab, Technical University of Crete. Prior to joining the Department of Environmental Engineering at TUC in 2015, he has been a faculty member at the Department of Agricultural Economics at the Agricultural University of Athens for 11 years. He worked in research in the Soil Institute and Plant Cultivation (IUNG) in Poland as visiting professor, in the Public Economics Unit in INRA at Grignon, France, started as Marie-Curie Fellow in 1997, then as post-doc in 2001 and senior researcher (2002-2004), and in the Mediterranean Agronomic Institute of Chania as post-doc for 12 months. Based on IDEA's RePEc's ranking list, he is currently ranked at the top $25 \%$ of economists in total 29072 in Europe and at the top $15 \%$ in Greece (publications in the last 10 years in RePEc Author Service).

His research interests focus on decision theory and modelling applied to agriculture and the bioeconomy with a record of over 50 peer-reviewed papers in scientific journals and book chapters comprising 2 special issues in international peer-review journals ( $\mathrm{J}$ of Technology Transfer and AgBioForum) in agricultural and environmental economics, energy policy as well as operations research journals (currently member of the Editorial Board of the Int J of Sustainable Agricultural Management and Informatics, and the Int $\mathbf{J}$ of Multi-criteria Decision Making). Organizing committee chair for the 146th EAAE (European Association of Agricultural Economists) Seminar «Technology transfer as a driver of innovative entrepreneurship in agriculture and the agri-food industry» in MAiCh, Greece in 2015, and Scientific \& Organizing Committee Chair for the 167th EAAE Seminar "European Agriculture and the Transition to Bioeconomy" in IUNG, Pulawy Poland in 2018.

E-mail: srozakis@iung.pulawy.pl 


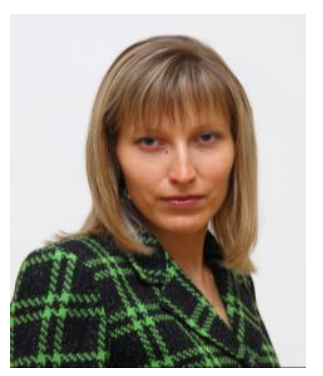

Inga Gulbe, Mg. philol., works as a researcher for Institute of Energy Systems and Environment, Riga Technical University. Also, she is a deputy director of Housing and Environment Department of Riga City Council. Main fields of her research interests cover district heating and housing energy efficiency.

E-mail: Inga.Gulbe@rtu.lv

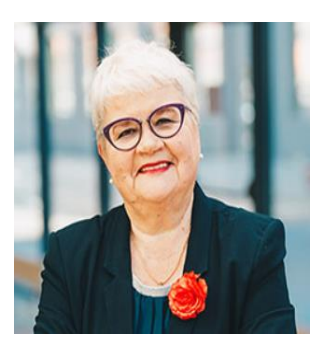

Dagnija Blumberga, Dr. habil. sc. ing. Professor, director of Institute of Energy Systems and Environment, Riga Technical University. She is an expert in bioeconomy, cleaner production, circular economy, renewable energy, climate change, biotechnologies and other environmental engineering themes. Author of more than 400 scientific publications. Hirsch index 20. She has an experience in international projects as project leader and expert. Member of Professor Council of Riga Technical University, Member of Professor Council Of university of Latvia.

E-mail: dagnija.blumberga@rtu.lv

ORCID iD: https://orcid.org/0000-0002-9712-0804

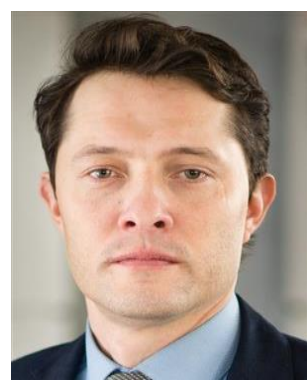

Oskars Krievs, Dr. sc. ing. He has received Bachelor's (2001), Master's (2003) and Doctor's (2007) degrees in the field of electrical engineering. He is working in Riga Technical University since 2001 and currently is in the positions of professor and dean of Faculty of Electrical and Environmental Engineering. His main research fields include active power filters, frequency converters and DC/DC converters.

E-mail: Oskars.Krievs@rtu.lv 